\title{
Use of Agro-Industrial Wastes for the Production of a Wild Yeast Enzyme with Disintegration Activity on Plant Tissues
}

\author{
Silvana Andrea Maidana ${ }^{*}$ \\ https://orcid.org/0000-0002-3115-9538 \\ Vanesa Paola Esteche ${ }^{1}$ \\ https://orcid.org/0000-0002-6876-6630
}

\section{Roque Alberto Hours ${ }^{2}$}

https://orcid.org/0000-0002-5173-4069

\section{Luis Alberto Brumovsky ${ }^{1}$}

https://orcid.org/0000-0002-9329-4276

\section{María Alicia Martos ${ }^{1}$ \\ https://orcid.org/0000-0003-1235-0529}

${ }^{1}$ Misiones National University Chemical and Life Sciences, School of Exact, Posadas, Misiones, Argentina. ${ }^{2}$ La Plata National University, School of Science, Research and Development Center for Industrial Fermentation (CINDEFI; UNLP, CONICET La Plata), La Plata, Argentina.

Received: 2019.08.28; Accepted: 2020.03.27.

*Correspondence: silvana.a.maidana@gmail.com; Tel.: +54-0376-154154077 (S. A. M.)

\section{HIGHLIGHTS}

- Use of residues for the PGase production represented an economic and sustainable method.

- The activity of PGase enhanced $37 \%$, with respect to the value obtained with original medium.

- PGase of $W$. anómalus was able to disintegrate cassava tuber tissue and release the starch granules.

Abstract: The objective of the present study was to develop a cost-effective medium, using agro-industrial wastes for the production of a polygalacturonase by Wickerhanomyces anomalus of interest in cassava starch industries.

The effect of several raw agro-industrial wastes and others nutrients on polygalacturonase production by W. anomalus, were evaluated, in a reference fermentation medium, using statistical designs, by batch culture. The ability of the cell-free supernatant to extract cassava starch was evaluated.

Lemon peel was the best inducer for the production of PGase. Statistical analysis of the data showed that lemon peel, $\mathrm{Mg}^{+2}$ and $\mathrm{PO}_{4} \mathrm{HK}_{2}$ had significant effect on $\mathrm{PG}$ ase production, and the others variables (yeast extract, $\mathrm{Ca}^{+2}, \mathrm{Fe}^{+2}$, amino acid and trace element solution) were no significant. PGase synthesis reached $\sim 31 \mathrm{EUmL}^{-1}$, in the OFM (glucose, lemon peel, urea, vitamins, $\mathrm{KH}_{2} \mathrm{PO}_{4}$ and $\mathrm{MgSO}_{4}$ ), after $12 \mathrm{~h}$ of culture, at a lab scale 
bioreactor. PGase of W. anomalus, was able to disintegrate cassava tuber tissue, and the starch granules contained within the cells were released into the reaction medium.

Lemon peel can be used as inducer for PGase production by W. anomalus, in a low cost culture medium, appropriate for the production of the enzyme at large scale.

Keywords: Wickerhanomyces anómalus; residues; Polygalacturonase; cassava starch extraction.

\section{INTRODUCTION}

The cost of the fermentation media is one of the determining factors in the production of enzymes. It is important to formulate a low cost culture medium and that it provide the nutritional requirements necessary for the proper growth of the microorganism [1-3]. Food and beverages industry generates, as a result of its activity, a large number of organic wastes as by-product of manufacturing processes. Consequently, the accumulation of great quantities of organic residues represents a risk to health and environment [4]. The production of microbial enzymes by a biotechnological process, using agricultural wastes in the culture medium, represents a suitable alternative for re-valorization of such a type of residues, reducing environmental pollution and generating products with high-added value, resulting in economic and ecological advantages [5-9].

Enzymes that disintegrate plant tissues are known as pectinolytic enzymes or pectinases. They constitute a group of enzymes that include polygalacturonase (PGase), pectin esterase (PE), and pectin lyase (PL) [1012]. These enzymes are used in the processing of fruits and vegetables and are traditionally classified into two groups according to extent of disintegration. One group contains those enzymes that can totally disintegrate plant tissues. They are used mainly in production of foodstuffs with high proportions of soluble solids like tomato paste or puree, and also to improve yields in fruit juice production. The other group includes the macerating enzymes, which can produce a suspension of loose single cells and are used to prepare fruit nectar bases, vegetable purees, and baby and geriatric foods [13-16].

The conventional method for optimizing enzyme production by one variable at a time approach involves varying a single independent variable, while maintaining the others at a constant level. This one-dimensional approach is laborious and time-consuming. An alternative and more efficient approach is the use of statistical methods. The design of Plackett-Burman is a fractional factorial design, very useful for preliminary studies where a large number of variables must be investigated and in which the use of a complete factorial model becomes impractical due to the large number of required tests. Response surface methodology (RSM) involves full factorial search by examining simultaneous, systematic and efficient variation of all components [13,17-19].

In our previous studies on native microorganism from Misiones Province, we isolate a pectinolytic yeast strain (Wickerhanomyces anomalus) which produces an extracellular PGase with disintegrating activity on plant tissues [20]. Analysis of the culture supernatants revealed only a single enzyme activity, namely endo-PGase (EC 3.2.1.15). This enzyme was purified and characterized [21,22].

PGase of W. anomalus, was able to disintegrate crude cassava tuber tissue, and the starch granules contained within the cells were released into the reaction medium. In the conventional process, cassava starch is produced primarily by the wet milling of fresh cassava roots. A substantial amount of starch grains are damaged particularly during the rasping/pulping/grating processes. In addition, these mechanical steps are critical to the economy of the process due to the high energy consumption [23-25]. Therefore, the production of cassava starch including an enzymatic step seems to be an interesting alternative in order increase the quality of the starch obtained and also to reduce the energy consumption of the process.

The objective of this paper was the biotechnological valorization of agro-industrial wastes in order to design a cost-effective medium for the production of PGase by W. anomalus, considering its potential application in cassava starch industries. 


\section{MATERIAL AND METHODS}

\section{Yeast strain}

W. anomalus, a yeast isolated from citrus fruit peels in the Province of Misiones, Argentina [20].

\section{Culture media}

Table 1 shows the composition of the Yeast medium (YM) used for the maintenance and propagation of W. anomalus and the composition of the Reference fermentation medium (RF medium) used for the production of the enzyme.

Table 1. Culture media.

\begin{tabular}{|c|c|}
\hline Yeast medium (YM) & $\left(g^{-1}\right)$ \\
\hline Glucose (Britania, Buenos Aires, Argentina) & 10 \\
\hline Yeast extract (Sigma Chemical Co., St. Louis, Mo, USA) & 5 \\
\hline tryptone (Difco-Becton Dickinson \&Co., Sparks, MD,USA) & 5 \\
\hline Agar (Britania) & 15 \\
\hline $\mathrm{pH}$ & 5.1 \\
\hline Reference fermentation medium (RF medium) [26] & $\left(\mathrm{gL}^{-1}\right)$ \\
\hline Glucose (Britania) & 10 \\
\hline Citrus pectin (Parafarm, Buenos Aires, Argentina) & 5 \\
\hline Urea & 1.4 \\
\hline $\mathrm{KH}_{2} \mathrm{PO}_{4}$ & 1 \\
\hline $\mathrm{MgSO}_{4}$ & 0.5 \\
\hline $\mathrm{CaCl}_{2}$ & 0.1 \\
\hline $\mathrm{FeCl}_{3} 6 \mathrm{H}_{2} \mathrm{O}$ & $200\left(\mu \mathrm{gL}^{-1}\right)$ \\
\hline vitamin solution & $(1000 \times) 1 \mathrm{mLL}^{-1}$ \\
\hline amino acid solution & $(100 \times) 10 \mathrm{mLL}^{-1}$ \\
\hline $\begin{array}{l}\text { trace element solution } \\
\mathrm{pH}\end{array}$ & $\begin{array}{l}(1000 \times) 1 \mathrm{mLL}^{-1} \\
5.1\end{array}$ \\
\hline Vitamin solution $(1000 \times)($ Sigma $)[27]$ & $\left(\mu \mathrm{gL}^{-1}\right)$ \\
\hline D-biotin & 2 \\
\hline calcium pantothenate & 400 \\
\hline Pyridoxine & 400 \\
\hline Thiamine & 400 \\
\hline Amino acid solution $(100 \times)($ Sigma $)[27]$ & $\left(\mathrm{mgL}^{-1}\right)$ \\
\hline Histidine & 10 \\
\hline Methionine & 20 \\
\hline Tryptophan & 20 \\
\hline Trace element solution $(1000 \times)$ & $\left(\mu g L^{-1}\right)$ \\
\hline $\mathrm{CuSO}_{4} \cdot 5 \mathrm{H}_{2} \mathrm{O}$ & 40 \\
\hline $\mathrm{MnSO}_{4} \cdot \mathrm{H}_{2} \mathrm{O}$ & 400 \\
\hline $\mathrm{NaMoO}_{4} \cdot 2 \mathrm{H}_{2} \mathrm{O}$ & 200 \\
\hline $\mathrm{ZnSO}_{4} \cdot 7 \mathrm{H}_{2} \mathrm{O}$ & 400 \\
\hline
\end{tabular}

Distilled water was used for culture media preparation. All components of the medium were autoclaved (121 $\stackrel{\circ}{ } \mathrm{C}, 15 \mathrm{~min})$, except in the case of vitamins and urea, which were sterilized separately by filtration through a cellulosic filter paper $(0.22 \mu \mathrm{m}$, Sartorius).

\section{Physicochemical characterization of agro-industrial residues}

Agro-industrial residues (peels of orange, tangerine, lemon, banana, passion fruit, pineapple, papaya and grapefruit), were provided by local industries of Misiones Province, Argentina.

All residues were dried overnight at $45^{\circ} \mathrm{C}$ in hot air drying oven (0.4 ms-1), milled (propeller mill Arcano, $24000 \mathrm{rpm}, 460 \mathrm{~W}$ ), passed through 35 mesh sieve to have uniform size particles of the material, and kept in air tight plastic containers for further analysis [28,29]. 
Maidana, S.A.; et al.

The agro industrial wastes were characterized by determining its centesimal composition. Carbohydrates, proteins, fats, dietary fiber, salts and ash content were determined using AOAC techniques [30]. Pectin was determined by measuring the amount of solubilized galacturonic acid (GA), by the m-hydroxy diphenyl method and was reported us $\mathrm{mg}$ of GA solubilized per $\mathrm{mg}$ of wet residue [31,32].

\section{Batch cultures of w. Anomalus, in flasks}

\section{Enzyme production}

Two hundred and fifty milliliter Erlenmeyer flasks with $45 \mathrm{~mL}$ of RF medium were inoculated with $5.0 \mathrm{~mL}$ of an appropriate dilution of a suspension of the microorganism (OD620 $=0.96)$, grown in YM medium $\left(30^{\circ} \mathrm{C}, 24\right.$ h). The Erlenmeyer flasks were incubated at $30^{\circ} \mathrm{C}, \mathrm{pH} 5.1$, for $16 \mathrm{~h}$, on a rotary shaker incubator (MRC, TOU$50 \mathrm{~N}, 25 \mathrm{~mm}$ shaking width) at $150 \mathrm{rpm}$ [33]. The biomass was separated by centrifugation at $2.350 \times \mathrm{g}$, at $5^{\circ} \mathrm{C}$, for $10 \mathrm{~min}$, washed carefully with sterile distilled water and used to inoculate subsequent fresh medium. Three precultures were performed. The fourth culture was centrifuged and the supernatant free of cells (enzymatic extract, EE) was frozen for further analytical assays [20].

\section{Selection of a pectin-containing material as inductor for PGase production}

Preliminary studies were carried out in order to select the best agro-industrial waste as inductor for PGase production by W. anomalus, using one variable at a time approach (OVAT) method12. OVAT approach is based on changing one variable at a time without studying the interaction among the tested variables [34,35].

The strain was cultivated in the RF medium, containing $4 \%(w v-1)$ of each agro-industrial waste, instead of commercial citrus pectin. The fermentations were carried out as mentioned above, and experiment runs in the original culture medium (RF) were considered as control $[6,8,36]$.

\section{Experimental design and statistical analysis for culture medium optimization}

\section{Plackett-Burman design}

The effect of different components in the RF medium containing the agro-industrial waste selected, instead of citrus pectin, for PGase production by W. anómalus, was evaluated. The mathematical method of PlackettBurman (PB) screening design was used to evaluate the effect of eight independent variables. The variables studied were: agro-industrial waste, yeast extract, $\mathrm{Ca}^{+2}, \mathrm{Mg}^{+2}, \mathrm{PO} 4 \mathrm{HK} 2, \mathrm{Fe}+3$, amino acids and trace elements. Each independent variable was analyzed at two levels: high $(+1)$ and low $(-1)($ Table 2). Based on the PB design, the corresponding matrix was obtained $[8,35,37]$. The fermentations were carried out as mentioned above and runs in the original RF medium, were considered as control.

Table 2. Factors, codes and real levels used in the Plackett-Burman design.

\begin{tabular}{llcc}
\hline \multirow{2}{*}{ Variables } & \multirow{2}{*}{ Code } & \multicolumn{2}{c}{ Level of variables } \\
\cline { 3 - 4 } & & $(+1)$ & $(-1)$ \\
\hline Lemon peel waste $\left(\% \mathrm{wv}^{-1}\right)$ & $\mathrm{A}$ & 10.00 & 2.00 \\
Yeast extract $\left(\mathrm{gL}^{-1}\right)$ & $\mathrm{B}$ & 1.50 & 0.00 \\
$\mathrm{Ca}^{+2}\left(\mathrm{gL}^{-1}\right)$ & $\mathrm{C}$ & 0.10 & 0.05 \\
$\mathrm{Mg}^{+2}\left(\mathrm{gL}^{-1}\right)$ & $\mathrm{D}$ & 0.25 & 0.12 \\
$\mathrm{PO}_{4} \mathrm{HK}_{2}\left(\mathrm{gL}^{-1}\right)$ & $\mathrm{E}$ & 0.50 & 0.25 \\
$\mathrm{Fe}^{+3}\left(\mathrm{gL}^{-1}\right)$ & $\mathrm{F}$ & 0.0001 & 0.00 \\
Amino acid solution & $\mathrm{G}$ & 1.00 & 0.00 \\
Trace element solution & $\mathrm{H}$ & 1.00 & 0.00 \\
\hline
\end{tabular}

\section{Doehlert experimental design}

The significant factors of the PB design were further optimized using response surface method (RSM) [38]. A design proposed by Doehlert was selected for studying the response surface [18, 19,39]. The real values of the independent variables were coded based on a linear functionality between codified $(Z)$ and actual values $(X)$ according to: 


$$
X=Z \times \frac{\Delta X}{\Delta Z}+X_{o}
$$

Where $X_{0}$ is the real value of the central point and $\Delta X$ and $\Delta Z$ are the difference between the highest and lowest values of real and coded numbers, respectively.

For simplicity a full quadratic model containing six coefficients was used to describe the response observed.

$$
\mathrm{Y}=\mathrm{b}_{0}+\sum \mathrm{b}_{\mathrm{i}} \mathrm{x}_{\mathrm{i}}+\sum \mathrm{b}_{\mathrm{ii}} \mathrm{x}_{\mathrm{ii}}^{2}+\sum \mathrm{b}_{\mathrm{ij}} \mathrm{x}_{\mathrm{j}}
$$

Where $Y$ is the response variable (PGase), $b_{0}$ a constant, and bi, bii, and bij are the coefficients for the linear, quadratic and interaction effect, respectively. The number of experiments required in this design ( $\mathrm{N})$ is given by $\mathrm{N}=\mathrm{n} 2+\mathrm{n}+\mathrm{n}_{0}$, where $\mathrm{n}$ is the number of variables and $\mathrm{n} 0$ is the number of central points. Replicates at the central level of the variables were performed in order to have an estimation of the experimental variance.

\section{Statistical analysis}

All experiments were carried out in triplicate and their mean values were used. The statistical software Stat Graphics was used for analyzing the experimental data [40].

\section{Validation of the experimental model}

To validate the model, additional runs were carried out for PGase production in shake flasks containing the optimized fermentation (OF) medium, predicted by the RSM [3,41].

\section{Bioreactor culture enzyme production}

Batch fermentations were performed in a $5 \mathrm{~L}$ bioreactor (New Brunswick) containing $3 \mathrm{~L}$ of the optimized fermentation medium (OF), at $30{ }^{\circ} \mathrm{C}$, with aeration (2.82 Lmin-1) and agitation (500 rpm), during $16 \mathrm{~h}$. Cultures were inoculated with an appropriate dilution of a suspension (in distilled water) of the microorganism, grown in Erlenmeyer flasks containing the same medium, at $30 \stackrel{\circ}{ }$, for $20 \mathrm{~h}$. Samples $(5 \mathrm{~mL})$ were collected at suitable periods of incubation $(1 \mathrm{~h})$ on an ice batch and centrifuged. The EE, free of cells, were frozen for further analytical assays.

\section{Application of the enzyme in cassava starch extraction}

It was evaluated the potentiality of W. anomalus EE, to extract cassava starch. Cassava tubers (Manihot esculenta Crantz) were provided by a local industry of Misiones Province, Argentina. Tubers were washed under tap water, peeled and cut into sheets of approximately $1 \mathrm{~cm}$ thick. Sheets were weighed and subjected to enzymatic treatment. The reaction mixture was incubated at $40{ }^{\circ} \mathrm{C}$, for $6 \mathrm{~h}$, on a rotary shaker incubator (MRC, TOU-50N, $25 \mathrm{~mm}$ shaking width) at $150 \mathrm{rpm}$. After incubation time, the resultant suspensions were filtered through a double fold muslin cloth into a beaker and the filtrate was centrifuged at $2.350 \times \mathrm{g}$ for $10 \mathrm{~min}$. The supernatants were discarded and the sediment was washed twice with distilled water, dried at $45^{\circ} \mathrm{C}$ for $24 \mathrm{~h}$ in hot air drying oven (0.4 ms-1) (Oven Universal, JSGW, ambala cantt., India). The dried starch was weighed, ground using a laboratory mill and then passed through 100 mesh sieve and kept in air tight plastic containers for further analysis [42].

The yield starch was expressed as percentage of extracted material (EM) with respect to the dry weight of the original tissue $(\% \mathrm{ww}-1)[43]$.

$$
\text { Yield }(\% w / w)=E M^{*}(g) x 100 / \text { cassava }(g)
$$

In addition, it was evaluated, the starch extraction using a commercial pectinolytic enzyme (Novozym 33095, Frutos Patagónicos S.R.L., Argentina). The enzyme was diluted in order to obtain an extract enzymatic with a PGase activity similar to that of W. anomalus EE, and the starch extraction was carried out as mentioned above. Runs with distilled water instead of the enzymes, were considered as control. All experiments were carried out in triplicate and average values were taken for the calculations. 


\section{Analytical methods}

Glucose: was determined using the glucose-peroxidase (Glicemia, Wiener, Argentina) method.

Polygalacturonase activity: was assayed by measuring the reducing groups released from $2 \mathrm{gL}-1$ poligalacturonic acid (Sigma) solution, in sodium acetate/acetic acid buffer (0.2 M, pH 5.0) using Somogy-Nelson method. The reaction was carried out at $37^{\circ} \mathrm{C}$ for 10 minutes. A calibration curve was made using galacturonic acid (GA) as standard. One unit of PGase was defined as the amount of enzyme that releases $1 \mu \mathrm{mol}$ of GA per minute [26, 44-46].

\section{RESULTS}

\section{Physicochemical characterization of agro-industrial residues}

Table 3 shows the physicochemical determinations, on dry matter basis, of the agro-industrial residues.

Table 3. Physicochemical characterization of agro-industrial residues.

\begin{tabular}{cllllllll}
\hline Mesh $^{(1)}$ & Papaya & Pineapple & Orange & Tangerine & Lemon & Banana & Passion fruit & Grapefruit \\
\hline A & $6.3 \pm 0.16$ & $6.8 \pm 0.11$ & $8.1 \pm 0.15$ & $9.8 \pm 0.12$ & $4.6 \pm 0.14$ & $7.5 \pm 0.03$ & $3.9 \pm 0.15$ & $2.9 \pm 0.13$ \\
B & $12.1 \pm 0.04$ & $5.5 \pm 0.05$ & $3.8 \pm 0.03$ & $4.2 \pm 0.09$ & $9.0 \pm 0.01$ & $16.9 \pm 0.01$ & $6.1 \pm 0.01$ & $3.1 \pm 0.01$ \\
C & $45.7 \pm 0.03$ & $34.2 \pm 0.01$ & $51.3 \pm 0.03$ & $91.2 \pm 0.02$ & $26.6 \pm 0.06$ & $43.5 \pm 0.03$ & $21.1 \pm 0.03$ & $91.4 \pm 0.02$ \\
D & $6.7 \pm 0.01$ & $2.5 \pm 0.01$ & $3.2 \pm 0.01$ & $2.2 \pm 0.01$ & $3.7 \pm 0.04$ & $7.5 \pm 0.03$ & $4.9 \pm 0.01$ & $4.1 \pm 0.13$ \\
E & $288.4 \pm 0.01$ & $68.7 \pm 0.04$ & $45.4 \pm 0.05$ & $66.9 \pm 0.04$ & $21.6 \pm 0.01$ & $468.6 \pm 0.02$ & $291.8 \pm 1.27$ & $37.7 \pm 1.06$ \\
F & $0.1 \pm 0.21$ & $0.1 \pm 0.02$ & $0.02 \pm 0.07$ & $0.1 \pm 0.01$ & $0.4 \pm 0.02$ & $0.02 \pm 0.01$ & $0.1 \pm 0.01$ & $0.1 \pm 0.01$ \\
G & $83.9 \pm 0.05$ & $152.5 \pm 0.11$ & $107.3 \pm 0.01$ & $59.1 \pm 0.02$ & $168.4 \pm 0.18$ & $70.3 \pm 0.01$ & $215.12 \pm 0.03$ & $73.9 \pm 0.05$ \\
H & $6.2 \pm 0.78$ & $2.5 \pm 0.06$ & $36.6 \pm 0.73$ & $25.3 \pm 0.14$ & $129.6 \pm 0.41$ & $17.5 \pm 0.27$ & $32.80 \pm 0.66$ & $34.4 \pm 0.77$ \\
I & $8.1 \pm 0.09$ & $9.6 \pm 0.11$ & $9.4 \pm 0.22$ & $8.9 \pm 0.05$ & $7.9 \pm 0.08$ & $7.5 \pm 0.19$ & $8.3 \pm 0.12$ & $9.1 \pm 0.16$
\end{tabular}

A: protein, B: Ashes, C: Carbohydrates, D: Fats, E: Sodium, F: Calcium, G: Dietary (o crude) fiber, H: Galacturonic acid (mgGa/mgresidue), I: Water content, ${ }^{(1)} \mathrm{g} \%$ dry base.

The physicochemical analysis performed on different agro-industrial residues (Table 3 ) showed that the content of total protein was highest for tangerine peel ( 9.87\%),followed by orange peel ( 8.12\%) and lower for lemon peel ( 4.56\%).Grapefruit and tangerine wastes showed highest carbohydrates content with value of $\sim 91.41 \%$ and $\sim 91.20 \%$, respectively.

The content of ash (minerals) was between 3.05to $16.95 \%$, in the different residues evaluated.

Lemon peel presented the higher levels of calcium $\sim 0.39 \%$ and pectin (determined as GA, $\left.\sim 129.57 \mathrm{mg}_{\mathrm{GA}} / \mathrm{mg}_{\text {residue }}\right)$.

\section{Batch cultures of w. anomalus, in flasks}

\section{Selection of a pectin-containing material as inductor for PGase production}

Figure 1 shows the production of PGase by W. anomalus in the RF medium obtained at $16 \mathrm{~h}$ of culture, using different agro-industrial waste instead of commercial citrus pectin.

Enzyme activities are presented as percentage of that value attained with RF medium ( $30 \stackrel{\circ}{\circ}, 16 \mathrm{~h}-180 \mathrm{rpm})$, which accounted for $100 \%\left(19.57 \pm 0.55 \mathrm{EUmL}^{-1}\right)$.

Lemon peel waste, was the best inducer for the production of PGase by W. anomalus, it was obtained a relative activity of $105.09 \%(21.74 \mathrm{UEmL}-1)$ when compared with that level obtained using RF medium.

PGase production was $16.52 \pm 0.14 \mathrm{EUmL}^{-1}$ in the presence of orange, and this value has not significance difference $(p<0.005)$ when it was used grapefruit, tangerine or passion fruit, as inductors. The used of papaya or banana, resulted in a lower production of the enzyme. 
On the basis of these results, residue of lemon peels was selected as inductor for further experiments, in replacement of commercial citrus pectin and it contributes to the culture medium with other nutrients such us proteins, calcium and pectin.

\section{Experimental design and statistical analysis for culture medium optimization}

\section{Plackett-Burman design}

The matrix developed by the PB design, and the results (PGase activity) are presented in Table 4.The regression analysis is shown in Table 5 and in Figure 2 the Pareto chart.

Table 4. Plackett-Burman matrix (coded values) and PGase activity obtained.

\begin{tabular}{cccccccccc}
\hline Run & \multicolumn{8}{c}{ Variable(a) $^{(\mathrm{a})}$} \\
\cline { 2 - 8 } order & $\mathrm{A}$ & $\mathrm{B}$ & $\mathrm{C}$ & $\mathrm{D}$ & $\mathrm{E}$ & $\mathrm{F}$ & $\mathrm{G}$ & $\mathrm{H}$ & $\left.{ }^{1}\right)$ \\
\hline 1 & 1 & -1 & 1 & -1 & -1 & -1 & 1 & 1 & $6.89 \pm 0.78$ \\
2 & 1 & 1 & -1 & 1 & -1 & -1 & -1 & 1 & $13.63 \pm 0.48$ \\
3 & -1 & 1 & 1 & -1 & 1 & -1 & -1 & -1 & $20.87 \pm 1.40$ \\
4 & 1 & -1 & 1 & 1 & -1 & 1 & -1 & -1 & $20.56 \pm 1.03$ \\
5 & 1 & 1 & -1 & 1 & 1 & -1 & 1 & -1 & $21.46 \pm 2.85$ \\
6 & 1 & 1 & 1 & -1 & 1 & 1 & -1 & 1 & $13.11 \pm 2.14$ \\
7 & -1 & 1 & 1 & 1 & -1 & 1 & 1 & -1 & $26.59 \pm 1.26$ \\
8 & -1 & -1 & 1 & 1 & 1 & -1 & 1 & 1 & $28.12 \pm 1.12$ \\
9 & -1 & -1 & -1 & 1 & 1 & 1 & -1 & 1 & 28.802 .31 \\
10 & 1 & -1 & -1 & -1 & 1 & 1 & 1 & -1 & $21.82 \pm 1.70$ \\
11 & -1 & 1 & -1 & -1 & -1 & 1 & 1 & 1 & $13.76 \pm 1.76$ \\
12 & -1 & -1 & -1 & -1 & -1 & -1 & -1 & -1 & $11.64 \pm 2.50$ \\
\hline
\end{tabular}

(a) Mean of three values, SD within 10\%.A: Lemon peel (\%wv $\left.{ }^{-1}\right)$; B: yeast extract $\left(\mathrm{gL}^{-1}\right) ; \mathbf{C}: \mathrm{Ca}^{+2}\left(\mathrm{gL}^{-1}\right)$; D: $\mathrm{Mg}^{+2}\left(\mathrm{gL}^{-1}\right)$; E: $\mathrm{PO}_{4} \mathrm{HK}_{2}\left(\mathrm{gL}^{-1}\right) ; \mathbf{F}: \mathrm{Fe}^{+3}\left(\mathrm{gL}^{-1}\right)$; $\mathbf{G}$ :amino acid solution; $\mathbf{H}$ : trace element solution. ${ }^{\text {(b) Mean of }}$ three values, SD within $10 \%$.

Table 5. Analysis of variance (ANOVA) for the experimental parameters of PB design.

\begin{tabular}{llllll}
\hline Variable & SS & DF & MS & F-value & p-value \\
\hline A:Lemonpeelwaste & 869.78 & 1 & 869.78 & 14.82 & $0.03^{*}$ \\
B: yeast extract & 590.66 & 1 & 590.66 & 1.01 & $0.39^{* *}$ \\
$\mathrm{C}: \mathrm{Ca}^{+2}$ & 20.99 & 1 & 20.99 & 0.36 & $0.59^{* *}$ \\
$\mathrm{D}: \mathrm{Mg}^{+2}$ & 217.25 & 1 & 217.25 & 37.01 & $0.01^{*}$ \\
$\mathrm{E}: \mathrm{PO}_{4} \mathrm{HK}_{2}$ & 140.91 & 1 & 140.91 & 24.00 & $0.02^{*}$ \\
$\mathrm{~F}: \mathrm{Fe}^{+3}$ & 404.32 & 1 & 404.32 & 6.89 & $0.08^{* *}$ \\
$\mathrm{G}:$ amino acid solution & 836.17 & 1 & 836.17 & 1.42 & $0.32^{* *}$ \\
$\mathrm{H}: \quad$ trace element & 288.76 & 1 & 288.76 & 4.92 & $0.11^{* *}$ \\
solution & 176.10 & 3 & 587.01 & & \\
Error & 548.43 & 11 & & & \\
Corrected total & & & & &
\end{tabular}

${ }^{*}$ Significant values $(p<0.05) ;{ }^{* *}$ Non-significant values $(p>0.05)$; SM: Sum of squares; DF: degrees of freedom; MS: mean square. $\mathrm{R}^{2}: 0.97$.

Statistical analysis of the data (Table 5) showed that lemon peel, $\mathrm{Mg}^{+2}$ and $\mathrm{PO}_{4} \mathrm{HK}_{2}$ had significant effect on PGase production $(\mathrm{p}<0.05)$. The effect of the others variables (yeast extract, $\mathrm{Ca}^{+2}, \mathrm{Fe}^{+2}$, amino acids and trace 
element solution) were no significant. The R2 was 0.97 , indicating that $97 \%$ of the variability in the response could be explained by the model.

Pareto chart (Figure 2) indicates that $\mathrm{Mg}^{+2}$ and $\mathrm{PO}_{4} \mathrm{HK}_{2}$ presented a positive effect in the range investigated. Lemon peel had a negative influence which means that, decreasing the concentration of this element in the culture medium, it will enhance the enzyme synthesis.

It is important to mention that when using lemon peel in the RF medium, instead of pectin, the influence of yeast extract, $\mathrm{Ca}^{+2}, \mathrm{Fe}^{+2}$, amino acid and trace element solution were not significant, this would be due to the fact that this agro-industrial residue is also a mineral, vitamins and protein sources, as it was determined in the characterization of the lemon peel (Table 5).

Subsequent studies were conducted using modified RF medium (RFM), according to the results of the PB design. The significant and positive factors $\left(\mathrm{Mg}^{+2}\right.$ and $\left.\mathrm{PO}_{4} \mathrm{HK}_{2}\right)$ were maintained at its high level. The others no significant variables (yeast extract, $\mathrm{Fe}^{+2}, \mathrm{Ca}^{+2}$, amino acid and trace element solution), were omitted and pectin was replaced by lemon peel.

\section{Doehlert experimental design}

A response surface method was employed to find the optimal level of the variables lemon peel and fermentation time, for the production of PGase by W. anomalus, using the RFM medium. The Doehlert experimental design was applied. The number of central points value (n0) was fixed at 3 and with two factors, the total of points of Doehlert matrix was 9. Table 6 showed the matrix of the Doehlert design and the results of enzyme activity obtained in each experiment.

Table 6. Codified, actual values and PGase activity attained in the Doehlert design.

\begin{tabular}{ccccccc}
\hline & \multicolumn{2}{c}{ Codified value } & & \multicolumn{2}{c}{ Actual value } & \\
\cline { 2 - 3 } \cline { 5 - 6 } Exp. & $\begin{array}{c}\text { Lemon } \\
\text { peel } \\
\text { waste }\end{array}$ & $\begin{array}{c}\text { Fermentation } \\
\text { time }\end{array}$ & & $\begin{array}{c}\text { Lemon peel } \\
\text { waste }\left(\% \mathrm{pv}^{-1}\right)\end{array}$ & $\begin{array}{c}\text { Fermentati } \\
\text { on time }(\mathrm{h})\end{array}$ & $\begin{array}{c}\text { PGase activity(a) } \\
\left(\mathrm{EUmL}^{-1}\right)\end{array}$ \\
\hline 1 & 1 & 0 & & 10 & 7.5 & $0.44 \pm 0.16$ \\
2 & 0.50 & -0.86 & & 8 & 3 & $5.15 \pm 0.58$ \\
3 & -0.50 & -0.86 & & 4 & 3 & $7.52 \pm 0.34$ \\
4 & -1 & 0 & & 2 & 7.5 & $16.31 \pm 1.47$ \\
5 & -0.50 & 0.86 & & 4 & 12 & $125.51 \pm 1.45$ \\
6 & 0.50 & 0.86 & & 8 & 12 & $11.21 \pm 1.91$ \\
7 & 0 & 0 & & 6 & 7.50 & $1.12 \pm 1.71$ \\
8 & 0 & 0 & & 6 & 7.50 & $1.06 \pm 1.61$ \\
9 & 0 & 0 & & 6 & 7.50 & \\
\hline
\end{tabular}

(a) Mean of three values, SD within $10 \%$.

Regression coefficients were calculated in terms of coded values of independent variables and data were fitted to a second order polynomial equation (Equation 4).

PGase $\left(\frac{\mathrm{EU}}{\mathrm{mL}}\right)=11.13-7.81[$ Lemon peel waste $]+7.40[$ Fermentation time $]-2.75\left[\right.$ Lemon peel waste ${ }^{2}-$

5.98 [Lemon peel waste][Fermentation time] +3.06 [Fermentation time ${ }^{2}$

The regression coefficient found $(R 2=0.99)$ indicated that the model was able to explain more than $99 \%$ of the observed response. Lemon peel and fermentation time showed both linear and quadratic effect significative $(p<0.05)$, as well as their interactions, on PGase production. The most important factor was lemon peel, with the highest coefficient, followed by fermentation time.

Figure 3 shows the response surface curve of PGase production by W. anómalus as function of the two independent variables.

The synthesis of the enzyme, increased when lemon peel concentration decreased from $10 \%$ (wv- 1 ) to $2 \%$ (wv-1). As the fermentation time increased from $3 \mathrm{~h}$ to $12 \mathrm{~h}$, a higher PGase production was observed. 
The second order polynomial equation (eq. 4) determined a maximum PGase value of $30.06 \pm 1.27$ EUmL1 , in the medium containing $2 \%(w v-1)$ lemon peel at $12 \mathrm{~h}$ of culture, this value was higher to that obtained in RF medium.

The final composition of the Optimized Fermentation (OF) medium is shown in Table 7.

Table 7. Composition of the Optimized Fermentation Medium.

\begin{tabular}{ll}
\hline Component & \\
\hline Glucose & $10\left(\mathrm{gL}^{-1}\right)$ \\
Lemon peel waste & $2 \%\left(\mathrm{wv}^{-1}\right)$ \\
Urea & $1.4\left(\mathrm{gL}^{-1}\right)$ \\
$\mathrm{KH}_{2} \mathrm{PO}_{4}$ & $0.5\left(\mathrm{gL}^{-1}\right)$ \\
$\mathrm{Mg}^{+2}$ & $0.25\left(\mathrm{gL}^{-1}\right)$ \\
Vitamin solution & $1000 x$ \\
\hline
\end{tabular}

When estimating costs of the culture medium, it was obtained that the OF medium would cost US\$0.22L1 , this value is lower than that for RF medium (US\$1.2L-1).

\section{Validation of the experimental model}

The enzyme production attained in shake flasks, containing the culture medium described in Table 7 and with $2 \%$ of lemon peel was $31.12 \pm 0.39 \mathrm{UEmL}-1$, after $16 \mathrm{~h}$ of culture. Analysis of variance revealed no significant differences $(p<0.05)$ in PGase activity between predicted and experimental values, showing the validity of the model used.

\section{Bioreactor culture enzyme production}

The scaling-up effect on PGase production was evaluated in a $5 \mathrm{~L}$ bioreactor in the OF culture medium. Figure 4 shows the time course of a batch culture of W. anomalus in OF medium, at a laboratory scale bioreactor.

Figure 4 shows that the detectable production of PGase started at $2 \mathrm{~h}$, obtaining a maximum production at $12 \mathrm{~h}$, coinciding with glucose exhaustion. From this time, the enzymatic activity in the culture supernatant remained constant. It was obtained a maximum enzymatic production of $31.28 \pm 0.93 \mathrm{EUmL}-1$ at $12 \mathrm{~h}$. The $\mathrm{pH}$ decreased slightly during the culture from an initial value of 5.1, up to about 4.9 at the end of the fermentation process.

\section{Application of ee of w. Anomalus in cassava starch extraction}

Figure 5 shows the material extracted (ME) from cassava tubers (Manihot esculenta Crantz), after centrifugation. The ME (starch, ashes, fibers, fats and proteins), with PGasa of W. anomalus resulted $44.5 \pm$ $0.98 \%$ (gEM/gcassava dry). With the commercial enzyme, it was obtained a value of $40.14 \pm 0.48 \%$ ( $g$ EM/gcassava dry). The control, in which the starch extraction was runs with distilled water instead of enzymes, was $6.38 \pm 0.76 \%$.

\section{DISCUSSION}

Agro-industrial residues such as fruits peels are excellent substrates for bioprocesses in terms of its high content in carbohydrates, proteins, minerals salts, calcium, all essential nutrients for yeast grows. These materials, are natural source of pectic substances, and can be used as a substrate for the production of enzymes by microorganisms [47].

Larios and coauthors (1989) showed that endo-PGase production by Aspergillus sp. $\mathrm{CH}-\mathrm{Y}-1043$ was four times higher with lemon peel instead of pectin [48].Maller and coauthors observed that orange peel was the best PGase inducer for submerged fermentation [49]. According to Embaby and coauthors, orange peel residues proved to be the best inducer for PGase production by Bacillus licheniformis SHG10 [35]. Similar results were obtained by Anuradha and coauthors, in the production of a PGase by Aspergillus awamori MTCC 9166 [37].

The effect of different nutrients on microbial enzyme production has been subject of different publications. Rekha and coauthors observed that orange peel and $\mathrm{Mg}^{+2}$ had a great influence on PGase production by $\mathrm{T}$. 
frigidphilos profundus, whereas $\mathrm{Fe}^{+3}$ and $\mathrm{Ca}^{+2}$ showed less effect [50].According to Ortiz and coauthors, an increase in K2HPO4, traces solutions and $\mathrm{Ca}+2$ factors exerts a positive effect on PGase production by Aspergillus giganteus NRRL10. Yeast extract, and $\mathrm{Fe}^{+2}$ had insignificant effect on enzyme productivity [51]. Poondla and coauthors studied the influence of different metal ions in the production of PGase by Saccharomyces cerevisiae, the production of enzymes increased considerably with MnSO4> KH2PO4> ZnSO4> $\mathrm{CaCl}_{2}>\mathrm{MgSO}_{4}>\mathrm{CoCl}_{2}[9]$.

In this paper, the decreased in PGase production observed when lemon peel concentrations increased, might be due to the increase in the viscosity of the culture medium, which caused problems to maintain the homogeneity and oxygen transfer problems during the fermentation process [12,52].

According to Naidu and Panda (1998) higher concentrations of carbon source inhibit enzyme synthesis [53]. Pedrolli and Carmona (2008) observed A. giganteus produced significant pectin lyase activity in medium with orange waste contents, with peak production at $2 \%$ (wv-1) [54]. According to Ahmed and Mostafa (2013), orange bagasse constitutes an excellent inducer substrate for PGase production by P. pinophilum Hedg NRRL 3503, which represented $69.20 \%$ increase in enzyme production compared with control [6]. Ahmed and coauthors showed maximum enzyme activity under optimum orange peel concentration of $4 \%$ for pectinase production by A. niger [55]. Nayyar and coauthors incorporated separately $1 \%$ of each agro-industrial wastes (apple peel, orange peel, lemon peel, potato peel and wheat bran) in a selected medium for PGase production by Bacillus licheniformis KIBE-IB3, further increase in concentration decline the PGase production [56].

Maidana and coauthors reported a maximum production of PGase by W. anomalus of $25.52 \mathrm{UEmL}^{-1}$ in a medium composed of $\left(\mathrm{gL}^{-1}\right)$ : glucose, commercial citrus pectin, urea, yeast extract, $\mathrm{KH}_{2} \mathrm{PO}_{4}, \mathrm{CaCl}_{2}$ and $\mathrm{MgSO}_{4}$, in a batch system, at a lab scale bioreactor [19]. In this study it was obtained a highest production of the enzyme (31.28 $\left.\pm 0.93 \mathrm{EUmL}^{-1}\right)$, in an economical culture medium and using an agro-industrial waste.

In this paper was evaluated the potentiality of W. anomalus EE, to extract cassava starch. The EM extracted with PGasa of W. anomalus resulted $44.5 \pm 0.98 \%$ (gEM/gcassava dry). Similar findings were reported for cassava starch extraction by Dzogbefia and coauthors using pectinase enzyme and by Sit and coauthors for taro starch extraction using cellulase and xylanase $[57,58]$.

The optimization of the cassava starch extraction with W. anómalus PGase, the comparison and feasibility of costs with industrial processes, will be presented in a next work.

\section{CONCLUSIONS}

The production of PGase by W. anomalus, using agricultural wastes, such as lemon peel in the culture medium, represented a suitable alternative for re-valorization of such a type of residues.

The optimized fermentation medium included glucose, lemon peel, urea, vitamins, KH2PO4 and MgSO4. The activity of PGase was enhanced in almost $37 \%$, with respect to the value obtained with original Reference Fermentation medium.

PGase of W. anómalus was able to disintegrate completely cassava tuber tissue, and the starch granules contained within the cells were released into the reaction medium, resulting in a novel biotechnological method, alternative to the traditional one by mechanical means.

Funding: This research was funded by National Interuniversity Council (CIN) (grant number 1055/15), University Policy Secretary (SPU) (grant number SPU 4508, Project 33-63-076) and School of Exact and Natural Sciences, Misiones National University to M. A. Martos. S. A. Maidana has a Doctoral Fellowship from Argentina National Research Council (CONICET) (grant number 4823/14).

Acknowledgments: The authors wish to thank Valeria Fernandez Müller, Undergraduate Fellows from Executive Committee for Development and Technological Innovation (CEDIT), for the help assistance during the fermentative processes.

Conflicts of Interest: The authors declare no conflict of interest. 


\section{REFERENCES}

1. Nighojkar S, Phanse Y, Sinha D, Nighojkar A, Kumar A. Production of polygalacturonase by immobilized cells of Aspergillus niger using orange peel as inducer. Process Biochem. 2006 Dec;41(5):1136-40.

2. Mahesh N, Vivek, R, Arunkumar M, Balakumar S. Statistical designing of enriched pectin extract medium for the enhanced production of pectinase by Aspergillus niger. Inter. J. Pharm. Pharm. Sci. 2014 Feb;6(SUPPL. 2):666-72.

3. Uzuner S, Cekmecelioglu D. Enhanced pectinase production by optimizing fermentation conditions of Bacillus subtilis growing on hazelnut shell hydrolyzate. J. Mol. Catal. B Enzym. 2015 Jan;113:62-7.

4. Jegannathan $\mathrm{KR}$, Nielsen $\mathrm{PH}$. Environmental assessment of enzyme use in industrial production-a literature review. J. Clean Prod. 2013 Nov;42:228-40.

5. Liguori R, Amore A, Faraco V. Waste valorization by biotechnological conversion into added value products. Appl. Microbiol. Biotechnol. 2013 May;97:6129-47.

6. Ahmed SA, Mostafa FA. Utilization of orange bagasse and molokhia stalk for production of pectinase enzyme. Braz. J. Chem. Ing. 2013 Aug;30(3):449-56.

7. Mamma D, Christakopoulos P. Biotransformation of Citrus By-Products into Value Added Products. WASTE BIOMASS VALORI. 2014 Jun;5(4):529-49.

8. Ortiz GE, Guitart ME, Cavalitto SF, Albertó EO, Fernández-Lahore M, Blasco M. Characterization, optimization, and scale-up of cellulases production by Trichoderma reesei cbs 836.91 in solid-state fermentation using agro-industrial products. Bioprocess Biosyst. Eng. 2015 Jul;38(11):2117-28.

9. Poondla V, Yannam SK, Gummadi SN, Subramanyam R, Reddy Obulam VS. Enhanced production of pectinase by Saccharomyces cerevisiae isolate using fruit and agro-industrial wastes: Its application in fruit and fiber processing. Biocatal. Agric. Biotechnol. 2016;6:40-50.

10.Jayani RS, Saxena S, Gupta R. Microbial pectinolytic enzymes: a review. Process Biochem. 2005 Mar;40:2931-44.

11. Tari C, Gögus N, Tokatli F. Optimization of biomass, pellet size and polygalacturonase production by Aspergillus sojae ATCC 20235 using response surface methodology. Enzym. Microb. Technol. 2007 Aug;40(5):1108-16.

12. Rehman HU, Qader SAU, Aman A. Polygalacturonase: production of pectin depolymerising enzyme from Bacillus licheniformis KIBGE IB-21. Carbohydr. Polym. 2012 May;90(1):387-91.

13. Cavalitto SF, Mignone CF. Application of factorial and Doehlert designs for optimization of protopectinase production by a Geotrichum klebahnii strain. Process Biochem. 2007 Jul;42(2):175-79.

14.Rojas NL, Cavalitto SF, Mignone CF, Hours RA. Role of PPase-SE in Geotrichum klebahnii, a yeast-like fungus able to solubilize pectin. Electron. J. Biotechnol. 2008 Jan;11(1):1-8.

15. Rojas NL, Ortiz GE, Chesini M, Baruque DJ, Cavalitto SF. Optimization of the production of polygalacturonase from Aspergillus kawachii cloned in Saccharomyces cerevisiae in batch and fed-batch cultures. Food Technol. Biotechnol. 2011 Feb;49(3):316-21.

16. Chen J, Yang R, Chen M, Wang S, Li P, Xia Y, et al. Production optimization and expression of pectin releasing enzyme from Aspergillus oryzae PO. Carbohydr. Polym. 2014 Sep;101:89-95.

17.Sharma D.C. and Satyanarayana T. A marked enhancement in the production of a highly alkaline and thermostable pectinase by Bacillus pumilus dcsr1 in submerged fermentation by using statistical methods. Bioresour. Technol. 2006 Apr;97:727-33.

18. Butiuk AP, Maidana SA, Martos MA, Akakabe Y, Adachi O, Hours RA. Characterization and application of fungal chlorogenate hydrolase to enzymatic breaking down of chlorogenate from yerba mate. Biocatal. Agric. Biotechnol. 2018 Apr;14:395-401.

19. Maidana SA, Butiuk AP, Zubreski ER, Hours RA, Brumovsky, LA, Martos MA. Production of an endopolygalacturonase from Wickerhanomyces anomalus with disintegration activity on plant tissues. Biocatal. Agric. Biotechnol. 2019 Feb;18.

20. Martos MA, Zubreski ER, Combina M, Garro OA, Hours RA. Isolation of a yeast strain able to produce a polygalacturonase with maceration activity of cassava roots. Food Sci. Technol. 2013 Mar;33(2):332-8.

21. Martos MA, Zubreski ER, Garro OA, Hours RA. Production of pectinolytic enzymes by the yeast Wickerhanomyces anomalus isolated from citrus fruits peels. Biotechnol. Res. Int. 2013b:1-7.

22. Martos MA, Butiuk AP, Rojas NL, Hours RA. Purification and characterization of a polygalacturonase produced by Wickerhamomyces anomalus. Braz. Arch. Biol. Technol. 2014 Feb;57(4):587-94.

23. Cobana M, Antezana R. Proceso de extracción de almidón de yuca por vía seca. Revista Boliviana de Química. 2007; 24(1):77-83 (in Spanish).

24. Torre P, Pérez A, Marmolejo LF, Ordóñez JA, García RE. Una mirada a la agroindustria de extracción de almidón de yuca, desde la estandarización de procesos. Revista EIA. 2010 Aug;14:23-38. (in Spanish).

25. Brousse MM, Nieto AB, Linares AR, Vergara ML. Cinética de absorción de agua en purés deshidratados de mandioca (Manihot esculenta crantz). 2012 May; RVCTA. 3 (1): 080-096 (in Spanish).

26. Cavalitto SF, Hours RA, Mignone CF. Growth and protopectinase production of Geotrichum klebahnii in batch and continuous cultures with synthetic media. J. Ind. Microbiol. Biotechnol. 2000 Sep;25:260-5. 
27. Martos MA. Estudio de enzimas pécticas producidas por microorganismos autóctonos (PhD. Thesis). Presidencia Roque Sáenz Peña, Chaco, Argentina: Universidad Nacional del Chaco Austral; 2012, 149 p.

28. Botella C, Diaz A, de Ory I, Webb C, Blandino A. Xylanase and pectinase production by Aspergillus awamori on grape pomace in solid state fermentation. Process Biochem. 2007 Jun;42(1):98-101.

29.Göğüş N, Evcan E, Tari C, Cavalitto SF. Evaluation of agro-industrial wastes, their state, and mixing ratio for maximum polygalacturonase and biomass production in submerged fermentation. Environm. Technol. 2015 May;36(20):2657-67.

30.A.O.A.C. 1990. Official Methods of Analysis of Association of Official Analytical Chemist International; EUA.

31. Melton LD, Smith BG. Determination of the uronic acid content of plant cell walls using a colorimetric assay. Food Analytic. Chem. 2001; E3.3.1-E3.3.4.

32.Vasco-Correa J, Zapata Zapata AD. Enzymatic extraction of pectin from passion fruit peel (Passifloraedulis f. flavicarpa) at laboratory and bench scale. LWT - FoodSci. Technol. 2017 Feb;80:280-5.

33. Maidana SA, Mieres AA, Zubreski ER, Martos MA. Optimización de las condiciones de cultivo para la producción de una poligalacturonasa microbiana. Revista de Ciencia y Tecnología. 2019b Feb; 32. (in press).

34. Hoa BT, Hung PV. Optimization of nutritional composition and fermentation conditions for cellulase and pectinase production by Aspergillus oryzae using response surface methodology. Inter. Food Res. J. 2013 Jul;20(6):3269-74.

35. Embaby AM, Masoud AA, Marey HS, Shaban NZ, Ghonaim TM. Raw agro-industrial orange peel waste as a low cost effective inducer for alkaline polygalacturonase production from Bacillus licheniformis SHG10. SpringerPlus. 2014 Jun; $3(1): 1-13$.

36.Göğüş N, HakgüderTaze B, Demir H, Tari C, Ünlütürk S, Lahore MF. Evaluation of orange peel, an industrial waste, for the production of Aspergillus sojae polygalacturonase considering both morphology and rheology effects. Turkish J. Biol. 2014 Apr;38(4):537-48.

37. Anuradha K, Naga Padma P, Venkateshwar S, Reddy G. Selection of Nutrients for Polygalacturonase Production by Aspergillus awamori MTCC 9166 Using Plackett-Burman Design. Indian J. Biotechnol. 2014 Jul;13:502-7.

38. Cheng SW, Wang YF, Wang ML. Statistical optimization of medium compositions for alkaline protease production by newly isolated Bacillus amyloliquefaciens. Chem. Biochem. Eng. Quarterly. 2012 Jul;26(3):225-31.

39.Doehlert DH. Uniform shell designs. Appl. Stat. 1970;19(3):231-39.

40.Stat Graphics. Centurión XV, Statpoint Technologies, Inc., Warrenton, VA, USA, 2009.

41.Shabbiri K, Adnan A, Jamil S, Ahmad W, Noor B, Rafique HM. Medium optimization of protease production by Brevibacterium linens DSM 20158, using statistical approach. Braz. J. Microbiol. 2012 Jun;1051-61.

42.Zubreski ER. Aislamiento de Wickerhamomyces anomalus una levadura productora de poligalacturonasa con capacidad macerante de tejidos vegetales (Ms.Sc. Thesis). Misiones, Argentina: Facultad de Ciencias Exactas Químicas y Naturales, Universidad Nacional de Misiones; 2013. 70 p.

43. Nakamura T, Hours RA, Sakai T. Enzymatic maceration of vegetables with protopectinases. J. Food Sci. 1995; 60, 46872.

44. Herbert D, Phipps PJ, Strange RE. Chapter III Chemical Analysis of Microbial Cells. Methods Microbiol. 1971;5:209_ 344.

45.Ferreyra OA, Cavalitto SF, Hours RA, Ertola RJ. Influence of trace elements on enzyme production: protopectinase expression by a Geotrichum klebahnii strain. Enzyme Microb. Technol. 2002 May; 31 (4): 498-504.

46.Jayani RS, Shukla SK, Gupta R. Screening of Bacterial Strains for Polygalacturonase Activity: Its Production by Bacillus sphaericus (MTCC 7542). Enzym. Res. 2010 Oct;1-5.

47. Ruiz HA, Rodríguez-Jasso RM, Rodríguez R, Contreras-Esquivel JC, Aguilar CN. Pectinase production from lemon peel pomace as support and carbon source in solid-state fermentation column-tray bioreactor. Biochem. Eng. J. 2012 Mar;65:90-5.

48. Larios G, Garcia JM, Huitrón C. Endo-polygalacturonase production from untreated lemon peel by Aspergillus $s p$. $\mathrm{CH}-$ Y-1043. Biotechnol. Letters. 1989 Aug; 11 (10): 729-734.

49. Maller A, Damásio ARL, Silva TMD, Jorge JA, Terenzi HF, De MoraesPolizeli MDLT. Biotechnological potential of agroindustrial wastes as a carbon source to thermostablepolygalacturonase production in Aspergillusniveus. Enzym Res. 2011 Apr; 1-6.

50.Rekha VPB, Ghosh M, Adapa V, Oh, S-J, Pulicherla KK, SambasivaRao KRS. Optimization of Polygalacturonase Production from a Newly Isolated Thalassospira frigidphilos profundus to Use in Pectin Hydrolysis: Statistical Approach. BioMed. Res. Inter. 2013 Nov;1-12.

51. Ortiz GE, Ponce-Mora MC, Noseda DG, Cazabat G, Saravalli C, López MC, et al. Pectinase production by Aspergillus giganteus in solid-state fermentation: optimization, scale-up, biochemical characterization and its application in olive-oil extraction. J. Ind. Microbiol. Biotechnol. 2017 Nov;44(2):197-211.

52. Malvessi E, Da Silveira MM. Influence of medium composition and $\mathrm{pH}$ on the production of polygalacturonases by Aspergillus oryzae. Braz. Arch. Biol. Technol. 2004 Sep;47(5):693-702.

53.Naidu GSN, Panda T. Production of pectolytic enzymes - A review. Bioprocess Eng. 1998 Oct;19:355-61. 
54.Pedrolli DB, Gomes E, Monti R, Carmona EC. Studies on productivity and characterization of polygalacturonase from Aspergillus giganteus submerged culture using citrus pectin and orange waste. App. Biochem. Biotechnol. 2008 Sep;144(2):191-200.

55.Ahmed I, Zia MA, Hussain MA, Akram Z, Naveed MT, Nowrouzi A. Bioprocessing of citrus waste peel for induced pectinase production by Aspergillus niger; its purification and characterization. J. Radiation Research App. Sci. 2015 Nov;9(2):148-54.

56. Nayyar J, Faiza S, Afsheen A, Talat YM, Shah AUQ. Utilization of agro waste pectin for the production of industrially important polygalacturonase. Heliyon. 2017 Jun; 3.

57.Dzogbefia VP, Ofosu GA, Oldham JH. Evaluation of locally produced Saccharomyces cerevisiae pectinase enzyme for industrial extraction of starch from cassava in Ghana. Sci. Res. Essays. 2008 Jul;3(8):365-9.

58. Sit N, Deka SC, Misra S. Optimization of starch isolation from taro using combination of enzymes and comparison of properties of starches isolated by enzymatic and conventional methods. J. Food Sci. Technol. 2015 Jun;52(7):4324-32.

(C) 5 (5) 2020 by the authors. Submitted for possible open access publication under the terms and
conditions of the Creative Commons Attribution (CC BY NC) license
(https://creativecommons.org/licenses/by-nc/4.0/). 